\title{
Sciendo
}

\author{
Livros Novos \\ Publicados em 1996/1997
}

Desidério Murcho

Universidade de Lisboa

Disputatio No. 2

May 1997

DOI: 10.2478/disp-1997-0006

ISSN: 0873-626X 


\section{LIVROS NOVOS}

Publicados em 1996/97

\section{Geral e Introdução}

McGinn, Colin, The Character of Mind: An introduction to the philosophy of mind. (2nd edition) Oxford UP. 176 pp. $£ 11.99$

Hospers, John, An Introduction to Philosophical Analysis. (4th edition) Routledge: London. 282 pp. $£ 11.99$

Howson, Colin, Logic With Trees. An introduction to symbolic logic. Routledge: London. 224 pp. $£ 12.99$

Weston, Anthony, A Practical Companion to Ethics. OUP. 107 pp. $£ 7.99$

\section{Metafísica}

Coates, Paul e Daniel D. Hutto, eds., Current Issues in Idealism. Bristol: Thoemmes. 307 pp. $£ 14.95$

Copeland, B. J., ed., Logic and Reality: Essays on the Legacy of Arthur Prior. Oxford: Clarendon. 545 pp. $£ 60$

Double, Richard, Metaphilosophy and Free Will. Oxford UP. 176 pp. $£ 30$

Drees, Willem B., Religion, Science and Naturalism. Cambridge: CUP. 314 pp. $£ 40$

Drury, M. O’C., (David Berman, Michael Fitzgerald and John Hayes, eds.) "The Danger of Words" and writings on Wittgenstein. Bristol: Thoemmes. 225 pp. $£ 14.95$

Kane, Robert, The Significance of Free Will. Oxford UP. 268 pp. $£ 35$

Strawson, P. F., Entity and Identity and Other Essays. Oxford: Clarendon. 285 pp. $£ 35$

Tooley, Michael, Time, Tense and Causation. Oxford: Clarendon. 399 pp. $£ 40$

Ward, Keith, God, Chance and Necessity. Oxford: Oneworld. 212 pp. £9.99

Disputatio 2, Maio 1997 


\section{Teoria do Conhecimento}

Lehrer, Keith, Self-Trust: A study of reason, knowledge and autonomy. Oxford: Clarendon. 204 pp. $£ 13.99$

Lucey, Kenneth G., ed., On Knowing and the Known: Introductory readings in epistemology. Buffalo, NY: Prometheus. 437 pp. $£ 19.50$

\section{Filosofia da Ciência}

Drees, Willem B., Religion, Science and Naturalism. Cambridge: CUP. 314 pp. $£ 40$

Tooley, Michael, Time, Tense and Causation. Oxford: Clarendon. 399 pp. $£ 40$

Wallace, William A., The Modeling of Nature: Philosophy of science and philosophy on nature in synthesis. Washington, DC: Catholic University of America Press. 450 pp. $£ 31.50$

\section{Filosofia da Linguagem, Mente e Cognição}

Bennett, Jonathan, The Act Itself. Oxford: Clarendon Press. 238 pp. $£ 25$

Cassam, Quassim, Self and World. Oxford: Clarendon Press. 208 pp. £27

Dretske, Fred, Naturalizing the Mind. Harvard: MIT Press. 208 pp. $£ 18.95$

Franklin, Stan, Artificial Minds. Harvard: MIT Press. 449 pp. $£ 22.95$

Gallois, André, The World Without, the Mind Within: An essay on 1st-person authority. Cambridge: CUP. 213 pp. $£ 35$

Jacob, Pierre, What Minds Can Do: Intentionality in a non-intentional world. Cambridge: CUP. 299 pp. £14.95

Koethe, John, The Continuity of Wittgenstein's Thought. Ithaca, NY: Cornell UP. 188 pp. $£ 23.50$

Lowe, E. J., Subjects of Experience. Cambridge: CUP. 209 pp. $£ 32.50$

Lycan, William G., Consciousness and Experience. 204 pp. Harvard: MIT Press. $£ 29.50$

McGinn, Colin, The Character of Mind: An introduction to the philosophy of mind. (2nd edition) Oxford UP. 176 pp. £11.99

Millican, P. J. R. and A. Clark, eds., Machines and Thought: The legacy of Alan Turing. Vol. 1. Oxford: Clarendon. 297 pp. $£ 30$ 
Schechtman, Marya, The Constitution of Selves. Ithaca, NY: Cornell UP. 169 pp. $£ 19.95$

Shoemaker, Sydney, The First-Person Perspective and other essays. Cambridge: CUP. 278 pp. $£ 14.95$

Strawson, P. F., Entity and Identity and Other Essays. Oxford: Clarendon. 285 pp. $£ 35$

Swinburne, Richard, The Evolution of the Soul. (revised ed.) Oxford: Clarendon. 360 pp. $£ 15.99$

Tye, Michael, Ten Problems of Consciousness. A representational theory of the phenomenal mind. Harvard: MIT Press. 248 pp. $£ 24.95$

\section{Lógica e Filosofia da Matemática}

Copeland, B. J., ed., Logic and Reality: Essays on the Legacy of Arthur Prior. Oxford: Clarendon. 545 pp. $£ 60$

Haack, Susan, Deviant Logic, Fuzzy Logic. Chicago: University of Chicago Press. 320 pp. $£ 15.25$

Hintikka, Jaako, The Principles of Mathematics Revisited. Cambridge: CUP. 288 pp. $£ 40$

Howson, Colin, Logic With Trees. An introduction to symbolic logic. Routledge: London. 224 pp. $£ 12.99$

\section{Teoria da Decisão}

Mele, Alfred R., ed., The Philosophy of Action. Oxford UP. 314 pp. $£ 11.99$

\section{Ética e Filosofia Política}

Rawls, John, O Liberalismo Político. Trad. de João de Sedas Nunes. Lisboa: Presença. 375 pp. $5500 \$ 00$

Almond, Brenda, AIDS: A moral issue. The ethical, legal and moral aspects. Macmillan. 162 pp. $£ 15.99$

Baron, Marcia W., Kantian Ethics Almost without Apology. Ithaca, NY: Cornell UP. 244 pp. $£ 25.50$ 
Brennan, Samantha, Tracy Isaacs and Michael Milde, eds., A Question of Values: New Canadian perspectives in ethics and political philosophy. Amsterdam: Rodopi. 213 pp. $£ 27$

Crisp, Roger, and Michael Slote, eds., Virtue Ethics. Oxford UP. 284 pp. $£ 12.99$

Cupit, Geoffrey, Justice as Fittingness. Oxford: Clarendon. 185 pp. $£ 27.50$

Daniels, Norman, Justice and Justification: Reflective equilibrium in theory and practice. Cambridge: CUP. 365 pp. $£ 14.95$

Darwall, Stephen, Allan Gibbard and Peter Railton, Moral Discourse and Practice: Some philosophical approaches. Oxford UP. 422 pp. £14.99

Double, Richard, Metaphilosophy and Free Will. Oxford UP. 176 pp. $£ 30$

Engstrom, Stephen and Jennifer Whiting, eds., Aristotle, Kant, and the Stoics: Rethinking happiness and duty. Cambridge: CUP. 310 pp. $£ 35$

Goodin, Robert E., Utilitarianism as a Public Philosophy. Cambridge: CUP. 352 pp. $£ 13.95$

Goodin, Robert E. and Philip Pettit, eds., Contemporary Political Philosophy: An antology. Oxford: Blackwell. 648 pp. £16.99

Harper, Charles, ed., Impunity: An Ethical Perspective. Geneva: World Council of Churches. 140 pp. $£ 7.95$

Kane, Robert, The Significance of Free Will. Oxford UP. 268 pp. $£ 35$

LaFollette, Hugh, ed., Ethics in Practice: An anthology. Oxford: Blackwell. 703 pp. $£ 16.99$

Lamb, David, Death, Brain Death and Ethics. Aldershot: Avebury. 120 pp. $£ 32.50$

Long, A. A., ed., Problems in Stoicism. Athlone. 267 pp. $£ 16.95$

Mele, Alfred R., ed., The Philosophy of Action. Oxford UP. 314 pp. $£ 11.99$

Orwin, Clifford, and Nathan Tarcov, eds., The Legacy of Rousseau. Chicago UP. 331 pp. £14.95

Pojman, Louis P., ed., Equality: Selected readings. Oxford UP. 325 pp. $£ 15$

Riley, Patrick, Leibnitz' Universal Jurisprudence: Justice as the charity of the wise. Harvard: HUP. 388 pp. $£ 26.50$

Russell, Bertrand, Principles of Social Reconstruction. (1st pub. 1916) London: Routledge. 174 pp. $£ 9.99$

Schneewind, J. B., ed., Giving: Western ideas of philanthropy. Bloomington: Indiana UP. 230 pp. 224.95

Unger, Peter, Living High and Letting Die: Our illusion of innocence. Oxford: OUP. 187 pp. $£ 13.50$ 
Wallace, James D., Ethical Norms, Particular Cases. Ithaca, NY: Cornell UP. 171 pp. $£ 21.50$

Weston, Anthony, A Practical Companion to Ethics. OUP. 107 pp. £7.99

Westphal, Jonathan, ed., Justice. Indianapolis: Hackett. 212 pp. £6.95

Zagzebski, Linda Trinkaus, Virtues of the Mind: An inquiry into the nature of virtue and the ethical foundations of knowledge. Cambridge: CUP. 365 pp. $£ 15.95$

\section{Estética e Filosofia da Arte}

Harrison, Andrew, Philosophy and the Arts: Seeing and believing. Bristol: Thoemmes. 209 pp. £12.99

\section{Filosofia da Religião}

Drees, Willem B., Religion, Science and Naturalism. Cambridge: CUP. 314 pp. $£ 40$

Quinn, Philip L. and Charles Talafierro, eds., A Companion to Philosophy of Religion. Oxford: Blackwell. 639 pp. $£ 65$

Swinburne, Richard, The Evolution of the Soul. (revised ed.) Oxford: Clarendon. 360 pp. £15.99

Ward, Keith, God, Chance and Necessity. Oxford: Oneworld. 212 pp. £9.99

\section{História da Filosofia}

Descartes, Princípios de Filosofia. Trad. de Margarida Leão. Lisboa: Lisboa Editora. $550 \$ 00$

Ferreira, Maria Luísa e Maria Teresa Ximenez, Russell: Os Problemas da Filosofia. Porto: Texto Editora. $990 \$ 00$

Kant, Fundamentação da Metafisica dos Costumes. Trad. de Filipa Gottschalk. Lisboa: Lisboa Editora. $750 \$ 00$

Platão, Fédon. Trad. de M. Teresa Schiappa de Azevedo. Lisboa: Lisboa Editora. $850 \$ 00$

Platão, Górgias. Trad. de Margarida Leão. Lisboa: Lisboa Editora. $900 \$ 00$

Santo Anselmo, Proslógion. Trad. de António Soares Pinheiro. Lisboa: Lisboa Editora. $400 \$ 00$ 
Valadares, Pedro Miguel, Descartes: Os Princípios da Filosofia. Porto: Texto Editora. 1.120\$00

Barnes, Jonathan, and Miriam Griffin, Philosophia Togata 2: Plato and Aristotle at Rome. Oxford: Clarendon. 300 pp. $£ 40$

Brett, Annabel S., Liberty, Rigth and Nature: Individual rights in later scholastic thought. Cambridge: CUP. 254 pp. £35

Cohn-Sherbok, Dan, Medieval Jewish Philosophy: An introduction. Richmond: Curzon. 196 pp. $£ 12.99$

Della Rocca, Michael, Representation and the Mind-Body Problem in Spinoza. Oxford UP. 223 pp. $£ 30$

Drury, M. O’C., (David Berman, Michael Fitzgerald and John Hayes, eds.) "The Danger of Words" and writings on Wittgenstein. Bristol: Thoemmes. 225 pp. $£ 14.95$

Engstrom, Stephen and Jennifer Whiting, eds., Aristotle, Kant, and the Stoics: Rethinking happiness and duty. Cambridge: CUP. 310 pp. $£ 35$

Everson, Stephen, Aristotle on Perception. Oxford: Clarendon. 309 pp. $£ 35$

Gerson, Lloyd P., ed., The Cambridge Companion to Plotinus. Cambridge: CUP. 462 pp. $£ 14.95$

Hacker, P. M. S., Wittgenstein's Place in Twentieth-Century Analytic Philosophy. Oxford: Blackwell. 346 pp. $£ 14.99$

Irwin, Terence, Plato's Ethics. Oxford: OUP. 436 pp. $£ 40$

James, William, A Pluralistic Universe. (1st published 1909) Lincoln: Nebraska UP. 404 pp. £14

Kant, Immanuel (trans. by Mary J. Gregor), Pratical Philosophy. Cambridge: CUP. 668 pp. $£ 50$

Kant, Immanuel (trans. by Werner S. Pluhar), Critique of Pure Reason. 1030 pp. $£ 15.95$

Koethe, John, The Continuity of Wittgenstein's Thought. Ithaca, NY: Cornell UP. 188 pp. $£ 23.50$

Kretzmann, Norman, The Metaphysics of Teism: Aquinas' natural law theory in "Summa contra gentiles”, 1. Oxford: Clarendon. 302 pp. £35

Lewis, Frank A., and Robert Bolton, eds., Form, Matter, and Mixture in Aristotle. Oxford: Blackwell. 290 pp. £12.99

Locke, John (Kenneth P. Winkler, ed.), An Essay Concerning Human Understanding. (1st published) Indianapolis: Hackett. 380 pp. £6.95 
Locke, John (Ruth W. Grant and Nathan Tarcov, eds.), Some Thoughts concerning Education. (1st published 1706) Indianapolis: Hackett. 227 pp. $£ 7.95$

Long, A. A., ed., Problems in Stoicism. Athlone. 267 pp. $£ 16.95$

Marenbon, John, The Philosophy of Peter Abelard. Cambridge UP. 373 pp. $£ 40$

Mill, John Stuart (Alan Ryan, ed.), Mill: Texts, commentaries: A critical edition. Norton. 365 pp. $£ 6.95$

Orwin, Clifford, and Nathan Tarcov, eds., The Legacy of Rousseau. Chicago UP. 331 pp. $£ 14.95$

Riley, Patrick, Leibnitz' Universal Jurisprudence: Justice as the charity of the wise. Harvard: HUP. 388 pp. $£ 26.50$

Solomon, Robert C. and Kathleen Higgins, A Short History of Philosophy. OUP: 330 pp. $£ 14.95$

Taylor, C. C. W., ed., Oxford Studies in Ancient Philosophy. vol. 14. Oxford: Clarendon Press. 312 pp. $£ 35$

Themistius, On Aristotle "On the Soul”. Trans. by Robert B. Dodd. London: Duckworth. 247 pp. $£ 40$

Walsh, W. H., Kant's Criticism of Metaphysics. (1st pub 1975) Edinburgh UP. 265 pp. $£ 14.95$

Woolhouse, R. S., and Richard Francks, eds. and trans., Leibnitz's 'New System" and Associated Contemporary Texts. Oxford: Clarendon. 261 pp. $£ 35$

(Compilação de Desidério Murcho) 